\title{
THE EFFECT OF RECENT FIRE HISTORY ON THE ABUNDANCE AND VIABILITY OF LARGE SEEDS IN THE SOIL OF SCLEROPHYLL FOREST IN TASMANIA, AUSTRALIA
}

\author{
by Nicole Bezemer, J.B. Kirkpatrick and J.A. Wood
}

(with two text-figures, two plates, eight tables and one appendix)

\begin{abstract}
Bezemer, N., Kirkpatrick, J.B. \& Wood, J.A. 2013 (17:xii): The effect of recent fire history on the abundance and viability of large seeds in the soil of sclerophyll forest in Tasmania, Australia. Papers and Proceedings of the Royal Society of Tasmania 147: 41-50. https://doi.org/10.26749/rstpp.147.41 ISSN 0080-4703. School of Geography and Environmental Studies, University of Tasmania, Private Bag 78, Hobart, Tasmania 7001, Australia (NB*, JBK); Royal Tasmanian Botanical Gardens, Queens Domain, Hobart, Tasmania 7000, Australia (JAW). *Author for correspondence. Email address: nbezemer@gmail.com
\end{abstract}

\begin{abstract}
There are few data on the effects of recent fire history on the composition of soil seed banks in sclerophyll forest communities. We predicted that the abundance and viability of soil-stored seeds would vary with fire history. Soils were sampled from areas with six different fire histories on Mt Nelson, Tasmania, Australia. Large seeds were extracted by hand separation and tested for viability. Responses to at least one of the two strongly-correlated components of fire history were detected in several taxa and for native and exotic seed. Native seeds, exotic seeds, Astroloma humifusum seed and Exocarpos cupressiformis seed were all more abundant in the soils of areas with one or less fires in the last 60 years than in the soils of areas burnt five times over the last 60 years. The viability of $A$. humifusum seeds decreased with fire frequency. These results support the hypothesis that frequent and recent fire can deplete the soil seed bank, and reduce soil seed viability, at least for some large-seeded species and species groups.
\end{abstract}

Key Words: eucalypt forest, fire frequency, fire history, seed abundance, seed viability, soil seed bank, time-since-fire, Astroloma bumifusum, Exocarpos cupressiformis.

\section{INTRODUCTION}

The long-term storage of seed in the soil (geospory) is an important life history strategy in plants (Fenner 1985, Bell 2001, Merritt \& Rokich 2006). Soil seed banks provide a genetic reservoir, from which dormant seeds germinate simultaneously or intermittently once stimulated by environmental or disturbance cues (Merritt \& Rokich 2006). Seed banks are in a constant state of flux, with predation, decay and senescence, movement of seeds within the soil and germination acting to remove the seeds that are periodically deposited (Harper 1977).

Fire seasonality and intensity have been shown to affect the emergence and survival of several scleromorphic shrub species (Knox \& Clarke 2006). Responses to fire can be modified by other factors. For example, soil moisture, depth of seed placement in the soil, fire intensity and duration affect the germination of Dodonea viscosa (L.) Jacq. (Hodgkinson \& Oxley 1990).

Fire may also alter seed bank composition by altering above-ground species composition. In dry sclerophyll forest near Sydney approximately 60\% of floristic variation may be attributed to fire frequency (Morrison et al. 1995). Frequent fires may shift sclerophyllous communities towards resprouter dominance (Meney et al. 1994, Bell 2001), thus altering seed deposition and, consequently, the composition of the seed bank.

Seeds in the soil that do not germinate after the passage of fire are an important component of the residual seed bank (Auld \& Denham 2006). Fire may prevent seed bank replenishment, thus depleting the residual store. In several genera of Ericaceae and Restionaceae, there was less viable seed in recently burnt sites than recently unburnt sites, with the total numbers of seeds in the soil varying from 9000 seeds $/ \mathrm{m}^{2}$ in unburnt sites to around 1500 seeds $/ \mathrm{m}^{2}$ in burnt sites (Meney et al. 1994). In heath communities, fire can deplete the seedbank by half (Pierce \& Cowling 1991). In the jarrah (Eucalyptus marginata Sm.) forest of southwestern Australia, the germinable soil seedbank was greater three years after fire than in soils from sites burned one and 13-22 years ago (Koch et al. 2009). This previous work suggests that fire history has a strong influence on the persistent soil seed store.

Germination after fire does not fully explain depletion of the seedbank, even in communities adapted to fire. In Acacia suaveolens (Sm.) Willd., maximum post-fire seed rain coincides with the maturation of post-fire germinants, at approximately two to three years (Auld 1986). Soil seed stores peak 10 years after a fire, after which stores decline in abundance and viability with loss of adult fecundity and decay. Soil seed stores of other species, such as Grevillea barklyana F. Meull. ex Benth., peak 16 years after fire (Vaughton 1998). Therefore, the magnitude of the soil seed store will be influenced by primary juvenile periods and patterns of post-fire fecundity, both of which can potentially be affected by fire regime.

Much of the above work was based on germination trials, which may not provide a complete representation of the soil seed bank, although being highly efficient in revealing the presence and abundance of most species. Exocarpos cupressiformis Labill. and Astroloma humifusum (Cav.) R.Br., for example, are conspicuous elements of dry sclerophyll communities that are rarely recorded in germination trials. For example, Penman et al. (2008) did not record their presence in the seed bank, as both species, although present in the vegetation, failed to respond to treatments. The cues used to stimulate the germination of seeds in in situ trials may be different to the ones that break the dormancy of particular species (Ooi et al. 2007).

The seed banks of scleromorphic communities are poorly known in Tasmania. Gilfedder \& Kirkpatrick (1993) compiled a list of species observed in semi-natural 
paddocks in the Tasmanian Midlands, and recorded those they germinated from the soil seed bank. Wilkinson \& Jennings (1994) tested the regeneration capacity of Acacia melanoxylon R.Br. after fire in northwestern Tasmanian wet sclerophyll forests, and found that high intensity burning destroyed $67 \%$ of the viable seed in the uppermost part of the soil profile, and stimulated the germination of most of the remainder.

Although fire or fire-related cues are essential to break the dormancy of many species, fire also kills seeds in the soil, and temporarily prevents replenishment of the seed bank by killing adult and juvenile plants. We therefore test the hypothesis that the soil seed bank of geosporous species in dry sclerophyll forest is affected by variation in fire history. Our results are confined to large-seeded species to enable us to collect a number of samples sufficient to compare several fire histories. We use physical extraction and testing for viability, rather than germination trials, to ensure confidence in the completeness of the data for our subset of species.

\section{METHODS}

\section{Study area}

The study area is located on Mt Nelson, Hobart, Tasmania $\left(147^{\circ} 19^{\prime} \mathrm{E}, 42^{\circ} 54^{\prime} \mathrm{S}\right)$ in the property of the University of Tasmania (fig. 1). The area includes a north-south gully occupied by Eucalyptus globulus Labill. wet forest with an understorey dominated by tall shrubs and small trees, such as Beyeria viscosa (Labill.) Miq., Pomaderris apetala Labill., Bedfordia salicina (Labill.) DC., Exocarpos cupressiformis and Coprosma quadrifida (Labill.) B.L.Rob., with occasional emergent Acacia melanoxylon. To the east of the gully is a large tract of Allocasuarina verticillata (Lam.) L.A.S.Johnson dry forest, which also occurs in two smaller patches in the western part of the reserve (fig. 1). Here, the understorey ranges from sparse to shrubby, with common species including Bursaria spinosa Cav., Dodonea viscosa, Astroloma humifusum, and Lepidosperma laterale R.Br. To the west of the gully is Eucalyptus pulchella Desf./ E. viminalis Labill. dry forest, which extends in a wide tract along much of the western border. Bursaria spinosa and D. viscosa, as well as native grasses, ericaceous shrubs and sedges, are typical components of the understorey. The southern and highest part of the reserve is comprised mostly of E. pulchellal E. globulus/ E. viminalis/ E. ovata Labill. dry forest. The understory is diverse, including most species already listed and additional species, notably Epacris impressa Labill., Olearia ericoides (Steetz) N.A. Wakef., Ozothamnusferrugineus (Labill.) Sweet, Lissanthe strigosa (Sm.) R.Br., Goodenia ovata Sm. and Pultenaea juniperina Labill. Native grasses are prominent in the understorey. Small tracts of degraded E. obliqua L'Hér. dry forest and E. ovata dry forest occur along the southwestern perimeter (fig. 1).

\section{Field data collection}

Across the University Reserve, six different fire histories were mapped from aerial photographs or satellite images dated 1946, 1957, 1967, 1975, 1980, 1984, 1989, 2001, 2004, 2008 and 2012 (table 1, fig. 2). An equal number of sites (10 per fire history; 60 in total) were selected from each fire history. Sites were chosen within five metres of a mature Acacia tree to remove the current occurrence of the genus as a factor influencing seed distribution. For each site, vegetation type was recorded and plant species listed. Soil samples were collected from the uppermost $5 \mathrm{~cm}$ of soil using a metal ring with a diameter of $8 \mathrm{~cm}$. The soil sample for each site was made up of nine sub-samples, with a total dry weight of c. $900 \mathrm{~g} /$ sample.

\section{Laboratory analyses}

The soil samples were dried overnight and large seeds separated out by breaking up and passing the soil through a $1.7 \mathrm{~mm}$ sieve. As sifting did not remove all the soil, seeds were then separated by hand. To avoid measurement bias, each sample was identified by a number from 1 to 60 , instead of the area from which it was collected.

Seeds were identified by JAW using the seed collections held at the Royal Tasmanian Botanical Gardens. Some seeds were identifiable only to genus level. The seeds of different taxa were described and photographed (appendix 1). The viability of each seed was determined using the cut test of Terry et al. (2003). Seeds in which the embryo appeared intact and healthy, and the endosperm clean and firm, were classed as viable.

\section{Statistical analyses}

Minitab 16 (Minitab Inc. 2010) was used in all analyses. In vegetation in which structure and dominance can be strongly influenced by fire regime, floristic classifications can better reflect underlying environmental gradients, and can be a better integral of past vegetation conditions, than dominance/structural groups. For these reasons, floristic groups were generated from the above ground vegetation presence/absence data for each site. An agglomerative strategy using Euclidean distance and Ward's method was adopted. Five groups were selected as there was a marked difference in average distance values between five and four groups.

For taxa with sufficient seed-bank data, one-way ANOVA was used to determine whether the abundance of seed varied with the presence or absence of a species in the above-ground vegetation at each site. Areas with high fire frequency strongly tended to be those with a short time since the last fire. This strong inverse relationship between the two attributes of fire regime required two sets of models in which number of fires was the fixed variable in one set and time since fire was the fixed variable in the other set.

TABLE 1

Known fire histories of the University Reserve

\begin{tabular}{lcc}
\hline Fire history & $\begin{array}{c}\text { No. of } \\
\text { fires }\end{array}$ & $\begin{array}{c}\text { Time-since- } \\
\text { fire (years) }\end{array}$ \\
\hline No fire in last 50 years & 0 & c. 60 \\
Last fire 1967 & 1 & 45 \\
1967,1995 & 2 & 17 \\
$1967^{1}, 1995$ & 3 & 17 \\
$1967,1995,1998$ & 3 & 14 \\
$1967^{1}, 1995,1998,2006$ & 5 & 6 \\
\hline
\end{tabular}

${ }^{1}$ At least one low intensity fire between 1967 and 1995. 


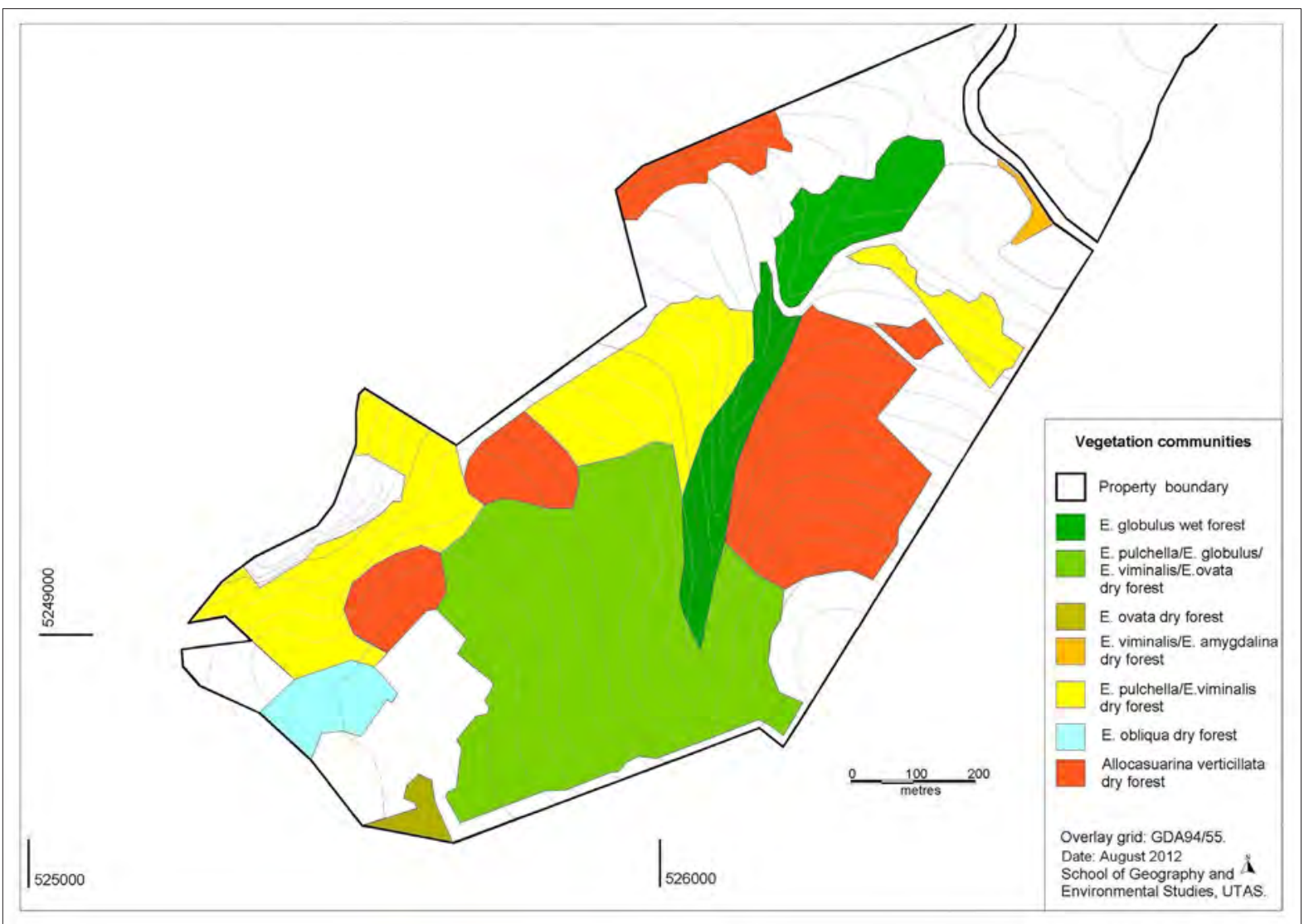

FIG. 1 - Vegetation types of the study area. Vegetation boundaries are based on the Biodiversity Management Plan (2012 draft) for the University Reserve. Base data from theLIST (www.thelist.tas.gov.au). () State of Tasmania

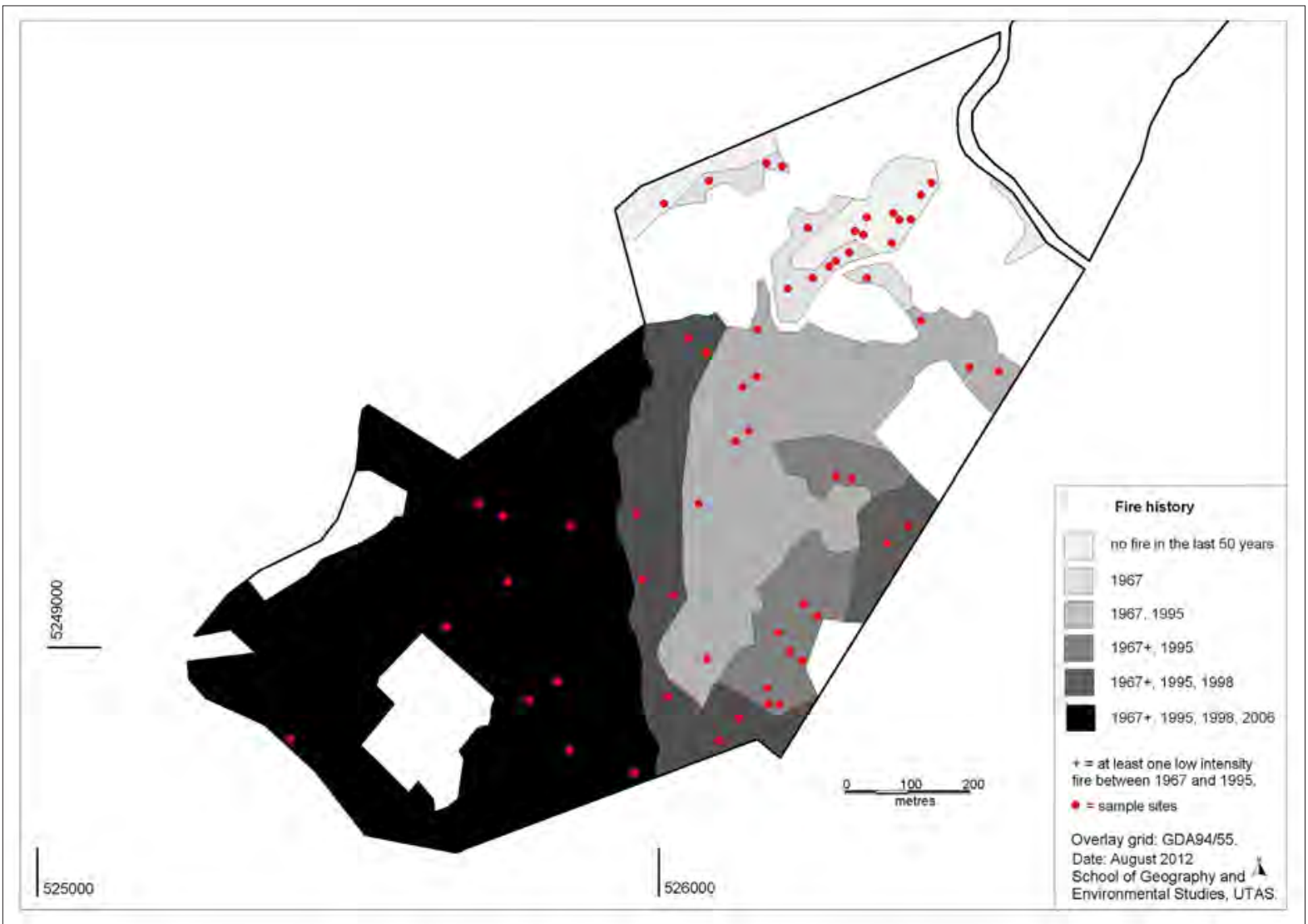

FIG. 2 - The recent fire history of the University Reserve, Tasmania $\left(147^{\circ} 19^{\prime} \mathrm{E}, 4^{\circ}{ }^{\circ} 4^{\prime} \mathrm{S}\right)$ and sample collection sites. Fire history boundaries are based on the Biodiversity Management Plan (2012 draft) for the University Reserve. Base data from theLIST (www.thelist.tas.gov.au). (C) State of Tasmania 
In both sets, vegetation type (five categories, as described above) and floristic group were included as random factors. The response variables were soil seed abundance for Acacia, Astroloma humifusum, Beyeria viscosa, Dodonea viscosa, Exocarpos cupressiformis, Lepidosperma laterale, Rubus fruticosus (L.) sp. agg., total native seed and total exotic seed. Two sets of general linear models with the same predictors were constructed for seed viability for those of the above species and species aggregates for which there were sufficient data.

\section{RESULTS}

Fourteen types of seed larger than $1.7 \mathrm{~mm}$ were found in the soil samples, 10 of which were identifiable to species or genus (appendix 1). Several of these taxa were too infrequent in the sample to analyse. The abundance of Beyeria viscosa seed in the soil was strongly related to its occurrence in the vegetation, whereas Astroloma humifusum, Dodonea viscosa, Exocarpos cupressiformis, Lepidosperma laterale, and Rubus fruticosus seed did not differ in abundance between sites in which they occurred and those in which they did not occur (table 2).

The number of fires between 1960 and 2012 was strongly related to the number of native and exotic seeds in the soil (table 3), seed number decreasing with the number of fires (table 4). A. humifusum, E. cupressiformis and R. fruticosus seed numbers also declined as the number of fires increased (tables 4 and 5). E. cupressiformis, as well as native and exotic seeds considered as a group, also had strong responses to time-since-fire (table 3). D. viscosa, B. viscosa, Acacia and $L$. laterale did not have a significant response to either number of fires or time-since-fire. While vegetation type was not significant in any of the models, floristic group affected the abundance of native, exotic, D. viscosa and $R$. fruticosus seeds in at least one of the analyses.

The seed viability of $A$. humifusum was related to the number of fires and time-since-fire (table 6). Native and E. cupressiformis seed viability was related to floristic group (table 5). Viability of native and $A$. humifusum seed was highest ( 46.8 and $53.3 \%$ respectively) in the area not burnt in the last 50 years and lowest (13.9 and 6.2\%) in the area burnt in 1967+, 1995 and 1998 (tables 7 and 8).

\section{DISCUSSION}

The 12 identified types of seed recovered from the soils of the study area (appendix 1) represented a small proportion of the 150 species of vascular plants recorded from the study area by one of us (JBK) and the 135 vascular plant species identified through germination trials in the soil seed bank of a grassy forest in southeastern Australia (Lunt 1997). Many species known to occur in the study area were not detected in the seed bank, despite having seeds $>1.7 \mathrm{~mm}$ in diameter. This result may indicate rarity of large seeds in the soil, or an insufficient sample size. Nevertheless, our procedures gave us confidence that our results reflected the reality of soil seed content for the subset of species with large seeds. We were able to count seeds of species, such as Exocarpos cupressiformis, that do not respond to normal germination trial procedures.

The distribution of the seed of Astroloma humifusum, Dodonea viscosa, E. cupressiformis, L. laterale and Rubus fruticosus was independent of the presence of the species in the contemporary vegetation (table 2), suggesting, in combination with the tendency of some of them to accumulate soil seed with time elapsed since fire, that these species have a persistent soil seed store. Among the above species, $A$. humifusum, E. cupressiformis and R. fruticosus have fleshy fruits or arils, so may be widespread in the soil seed store because of bird dispersal. The positive relationship between Beyeria viscosa soil seed and its contemporary presence in the vegetation reflects its restricted distribution in the study area and its lack of attraction for birds and mammals. The species was only found in wet eucalypt forest that had not been burned since 1967, where it had a substantial seed store, with more than $60 \%$ viability. Many of the viable seeds had heavily weathered coats, suggesting that this species has a persistent seed store.

Previous Tasmanian soil seed bank studies (Gilfedder \& Kirkpatrick 1993, Wilkinson \& Jennings 1994) did not record E. cupressiformis, A. humifusum or L. laterale, the seeds of which were common in our samples. In contrast, Acacia species have been observed to have a soil seed store (Wilkinson \& Jennings 1994), as in our study area.

There was a strong relationship between the least burned areas and the more mesic parts of the study area, although all fire histories had at least some wet and some dry forest. To the extent that was possible given this partial coincidence, we removed the effects of vegetation by making vegetation variables random within our models (tables 3 and 6). This modelling procedure accounts for the lack of statistical effect from the fire variables for seed numbers for several of our taxa and groups, despite the raw data (tables 4, 5, $7,8)$ suggesting stronger patterns. For example, the low mean abundance of $A$. humifusum seed in the areas with the longest time elapsed since fire (table 5) may be largely an artefact of its inability to survive in wet eucalypt forest.

The lack of influence in the models of the vegetation types, while floristic groups were shown to have some influence, suggests that longer term influences, such as environment and the integral of fire history, have more effect on the soil seed store than the structural-dominance vegetation types present at a particular time.

After accounting for the vegetation effect, we were able to demonstrate some strong associations between frequent and recent fire and low numbers and low viability of soil-stored seed. Native seeds in the soil, predominantly comprised of $A$. humifusum and $E$. cupressiformis, declined with increasing number of fires and decreasing time-sincefire (tables 3, 4, 5). These results complement the findings of previous studies that show a depletion of the soil seed store by fire (e.g., Meney et al. 1994, Pierce \& Cowling 1991, Wilkinson \& Jennings 1994). Our results show that the number of large native seeds in the soil is markedly lower in 17-year-old-burn sites compared to 45-year-old burn sites. These findings are very different to those of Koch et al. (2009), who reported recovery of the soil seed store within three years after fire, and a decline thereafter.

One explanation for the associations observed in the present study is the breaking of dormancy by heat or the chemicals in smoke. Non-viable seed accumulates after most soil seed germinates. Heat-initiated germination has been observed for Lepidosperma (Penman et al. 2008) and Acacia (Fryer 2006). Several species of Astroloma also respond to smoke as a germination cue (Fryer 2006), although this response has not been confirmed for $A$. humifusum. Our viability data strongly suggest that germination of $A$. 
TABLE 2

Mean number of seeds \pm standard error (n) per $900 \mathrm{~g}$ (dry weight) soil at collection sites with and without plant taxa present in the above ground vegetation

\begin{tabular}{lcccc}
\hline Species & Present & Absent & F value & P value \\
\hline Astroloma humifusum & $7.9 \pm 1.6(26)$ & $7.2 \pm 1.3(34)$ & 0.10 & 0.749 \\
Beyeria viscosa & $2.5 \pm 0.6(25)$ & $<0.1 \pm 0.03(35)$ & 21.98 & $<0.001$ \\
Dodonea viscosa & $1.4 \pm 0.5(44)$ & $0.7 \pm 0.3(16)$ & 0.70 & 0.405 \\
Exocarpos cupressiformis & $7.4 \pm 3.6(20)$ & $3.6 \pm 1.8(40)$ & 1.17 & 0.285 \\
Lepidosperma laterale & $0.4 \pm 0.2(28)$ & $1.0 \pm 0.7(32)$ & 0.58 & 0.449 \\
Rubus fruticosus & $0.0 \pm 0.0(57)$ & $0.7 \pm 0.2(3)$ & 0.58 & 0.450 \\
\hline
\end{tabular}

TABLE 3

Results of general linear model analyses for seed number

\begin{tabular}{|c|c|c|c|c|c|c|c|}
\hline \multirow[t]{3}{*}{ Response/fixed variable } & \multicolumn{2}{|c|}{ Fixed variable } & \multicolumn{4}{|c|}{ Random variables } & \multirow[t]{2}{*}{$\mathrm{R}^{2}(\%)$} \\
\hline & & & \multicolumn{2}{|c|}{ Vegetation type } & \multicolumn{2}{|c|}{ Floristic group } & \\
\hline & $\mathrm{F}$ & $\mathrm{P}$ & $\mathrm{F}$ & $\mathrm{P}$ & $\mathrm{F}$ & $\mathrm{P}$ & \\
\hline Native/fires ${ }^{1}$ & 6.01 & 0.001 & 1.43 & 0.239 & 3.29 & 0.019 & 59.26 \\
\hline Native/tsf ${ }^{2}$ & 5.30 & 0.001 & 0.91 & 0.464 & 4.23 & 0.005 & 57.58 \\
\hline Exotic/fires & 4.99 & 0.002 & 0.72 & 0.583 & 2.05 & 0.103 & 45.82 \\
\hline Exotic/tsf & 4.98 & 0.002 & 0.91 & 0.464 & 2.89 & 0.032 & 45.79 \\
\hline Acacia spp./fires & 0.88 & 0.485 & 0.32 & 0.865 & 0.83 & 0.511 & 18.18 \\
\hline Acacia spp./tsf & 0.89 & 0.476 & 0.33 & 0.857 & 0.91 & 0.463 & 18.28 \\
\hline Astroloma humifusum/fires & 3.29 & 0.019 & 2.16 & 0.088 & 0.79 & 0.541 & 33.16 \\
\hline Astroloma humifusum/tsf & 1.67 & 0.174 & 0.93 & 0.454 & 0.59 & 0.674 & 25.07 \\
\hline Beyeria viscosa/fires & 1.58 & 0.195 & 0.09 & 0.984 & 0.95 & 0.441 & 49.94 \\
\hline Beyeria viscosa/tsf & 1.56 & 0.201 & 0.07 & 0.991 & 0.94 & 0.451 & 49.84 \\
\hline Dodonea viscosal fires & 1.96 & 0.115 & 1.05 & 0.392 & 3.44 & 0.015 & 56.26 \\
\hline Dodonea viscosa/tsf & 1.91 & 0.125 & 1.18 & 0.332 & 6.29 & $<0.001$ & 56.07 \\
\hline Exocarpos cupressiformis/fires & 6.21 & $<0.001$ & 0.07 & 0.992 & 1.69 & 0.168 & 52.16 \\
\hline Exocarpos cupressiformis/tsf & 6.21 & $<0.001$ & 0.08 & 0.989 & 1.89 & 0.128 & 52.17 \\
\hline Lepidosperma laterale/fires & 0.81 & 0.527 & 0.04 & 0.997 & 1.44 & 0.235 & 21.82 \\
\hline Lepidosperma laterale/tsf & 0.83 & 0.513 & 0.05 & 0.995 & 1.44 & 0.237 & 21.95 \\
\hline Rubus fruticosus/fires & 2.67 & 0.044 & 1.05 & 0.394 & 2.03 & 0.105 & 48.72 \\
\hline Rubus fruticosus/tsf & 2.48 & 0.057 & 0.89 & 0.476 & 2.91 & 0.031 & 48.04 \\
\hline
\end{tabular}

${ }^{1}$ Fires $=$ number of fires since $1960,{ }^{2}$ tsf $=$ time since last fire.

TABLE 4

Means and standard errors for seed number related to number of fires (1960-2012)

\begin{tabular}{lcccccc}
\hline No. of fires & $\mathrm{n}$ & Native & Exotic & A. humifusum & E. cupressiformis & $R$. fruticosus \\
\hline 0 & 10 & $35.5 \pm 9.1 \mathrm{~A}$ & $12.2 \pm 9.9 \mathrm{~A}$ & $3.4 \pm 1.9 \mathrm{~A}$ & $23.3 \pm 7.7 \mathrm{~A}$ & $1.2 \pm 0.6 \mathrm{AB}$ \\
1 & 10 & $22.3 \pm 5.3 \mathrm{AB}$ & $3.8 \pm 1.4 \mathrm{~A}$ & $11.5 \pm 3.0 \mathrm{~A}$ & $4.1 \pm 1.9 \mathrm{~B}$ & $2.4 \pm 0.9 \mathrm{~A}$ \\
2 & 10 & $14.7 \pm 2.0 \mathrm{~B}$ & $0.7 \pm 0.4 \mathrm{~A}$ & $10.1 \pm 2.1 \mathrm{~A}$ & $1.2 \pm 0.5 \mathrm{~B}$ & $0.6 \pm 0.3 \mathrm{AB}$ \\
3 & 20 & $9.30 \pm 1.8 \mathrm{~B}$ & $0.5 \pm 0.2 \mathrm{~A}$ & $7.3 \pm 1.8 \mathrm{~A}$ & $0.4 \pm 0.2 \mathrm{~B}$ & $0.0 \pm 0.0 \mathrm{~B}$ \\
5 & 10 & $6.10 \pm 1.9 \mathrm{~B}$ & $0.4 \pm 0.2 \mathrm{~A}$ & $5.4 \pm 1.7 \mathrm{~A}$ & $0.0 \pm 0.0 \mathrm{~B}$ & $0.1 \pm 0.1 \mathrm{~B}$ \\
\hline
\end{tabular}


TABLE 5

Means and standard errors for seed number related to time-since-fire

\begin{tabular}{lcccc}
\hline $\begin{array}{l}\text { Time-since-fire } \\
\text { (years) }\end{array}$ & $\mathrm{n}$ & Native & Exotic & E. cupressiformis \\
\hline c. 60 & 10 & $35.5 \pm 9.1 \mathrm{~A}$ & $12.2 \pm 9.9 \mathrm{~A}$ & $23.3 \pm 7.7 \mathrm{~A}$ \\
45 & 10 & $22.3 \pm 5.3 \mathrm{AB}$ & $3.8 \pm 1.4 \mathrm{~A}$ & $4.1 \pm 1.9 \mathrm{~B}$ \\
17 & 20 & $12.1 \pm 1.9 \mathrm{~B}$ & $0.6 \pm 0.2 \mathrm{~A}$ & $0.7 \pm 0.3 \mathrm{~B}$ \\
14 & 10 & $9.0 \pm 2.0 \mathrm{~B}$ & $0.4 \pm 0.3 \mathrm{~A}$ & $0.6 \pm 0.3 \mathrm{~B}$ \\
6 & 20 & $6.1 \pm 1.9 \mathrm{~B}$ & $0.4 \pm 0.2 \mathrm{~A}$ & $0.0 \pm 0.0 \mathrm{~B}$ \\
\hline
\end{tabular}

TABLE 6

Results of general linear model analyses for the viability (\%) of seed of selected species

\begin{tabular}{|c|c|c|c|c|c|c|c|}
\hline \multirow[t]{2}{*}{ Response/fixed variable } & \multicolumn{2}{|c|}{ Fixed variable } & \multicolumn{4}{|c|}{ Random variables } & $\mathrm{R}^{2}(\%)$ \\
\hline & $\mathrm{F}$ & $\mathrm{P}$ & $\mathrm{F}$ & $\mathrm{P}$ & $\mathrm{F}$ & $\mathrm{P}$ & \\
\hline Native/fires ${ }^{1}$ & 1.33 & 0.275 & 0.17 & 0.953 & 5.81 & 0.001 & 71.06 \\
\hline Native/tsf ${ }^{2}$ & 1.33 & 0.275 & 0.19 & 0.942 & 6.46 & $<0.001$ & 71.02 \\
\hline Acacia spp./tsf & 0.82 & 0.554 & 0.59 & 0.671 & 0.72 & 0.584 & 20.37 \\
\hline Astroloma humifusum/fires & 3.48 & 0.016 & 0.28 & 0.889 & 2.01 & 0.109 & 30.58 \\
\hline Astroloma humifusum/tsf & 3.60 & 0.014 & 0.85 & 0.438 & 2.19 & 0.084 & 32.72 \\
\hline Exocarpos cupressiformis/fires & 0.41 & 0.746 & 0.06 & 0.992 & 2.76 & 0.038 & 69.78 \\
\hline
\end{tabular}

${ }^{1}$ Number of fires since $1960,{ }^{2} \mathrm{tsf}=$ time since last fire.

TABLE 7

Means and standard errors (n) of seed viability (\%) related to number of fires (1960-2012)

\begin{tabular}{lcccccc}
\hline $\begin{array}{l}\text { No. of } \\
\text { fires }\end{array}$ & A. humifusum & Acacia spp. & B. viscosa & D. viscosa & E. cupressiformis & Natives \\
\hline 0 & $53.3 \pm 17.4(7) \mathrm{A}$ & $81.9 \pm 11.9(4) \mathrm{A}$ & $60.9 \pm 13.0(9) \mathrm{A}$ & $100.0 \pm 0.0(8) \mathrm{A}$ & $31.7 \pm 6.8(10) \mathrm{A}$ & $46.8 \pm 7.7(10) \mathrm{A}$ \\
1 & $24.0 \pm 7.2(10) \mathrm{AB}$ & $90.0 \pm 10.0(4) \mathrm{A}$ & $63.1 \pm 15.0(8) \mathrm{A}$ & $74.1 \pm 14.0(7) \mathrm{A}$ & $28.3 \pm 10.0(8) \mathrm{A}$ & $36.9 \pm 6.6(10) \mathrm{AB}$ \\
2 & $19.8 \pm 5.2(10) \mathrm{B}$ & $75.0 \pm 25.0(4) \mathrm{A}$ & - & $70.6 \pm 16.1(6) \mathrm{A}$ & $28.6 \pm 18.4(7) \mathrm{A}$ & $33.0 \pm 4.9(10) \mathrm{AB}$ \\
3 & $13.7 \pm 3.4(16) \mathrm{B}$ & $66.7 \pm 23.6(4) \mathrm{A}$ & - & $100.0 \pm 0.0(4) \mathrm{A}$ & $0.0 \pm 0.0(3) \mathrm{A}$ & $19.7 \pm 6.0(19) \mathrm{B}$ \\
5 & $6.2 \pm 6.2(8) \mathrm{B}$ & $66.7 \pm 33.3(3) \mathrm{A}$ & - & $100.0 \pm 0.0(1) \mathrm{A}$ & & $13.9 \pm 6.7(8) \mathrm{B}$ \\
\hline
\end{tabular}

TABLE 8

Means and standard errors (n) of seed viability (\%) related to time-since-fire (years)

\begin{tabular}{|c|c|c|c|c|c|c|}
\hline $\begin{array}{l}\text { Time- } \\
\text { since- } \\
\text { fire }\end{array}$ & A. humifusum & Acacia spp. & B. viscosa & D. viscosa & E. cupressiformis & Natives \\
\hline 50 & $53.3 \pm 17.4(7) \mathrm{A}$ & $81.9 \pm 11.9(4) \mathrm{A}$ & $60.9 \pm 13.0(9) \mathrm{A}$ & $100.0 \pm 0.0(8) \mathrm{A}$ & $31.7 \pm 6.8(10) \mathrm{A}$ & $46.8 \pm 7.7(10) \mathrm{A}$ \\
\hline 45 & $24.0 \pm 7.2(10) \mathrm{AB}$ & $90.0 \pm 10.0(4) \mathrm{A}$ & $63.1 \pm 15.0(8) \mathrm{A}$ & $74.1 \pm 14.0(7) \mathrm{A}$ & $28.3 \pm 10.0(8) \mathrm{A}$ & $36.9 \pm 6.6(10) \mathrm{AB}$ \\
\hline 17 & $19.2 \pm 3.7(17) \mathrm{B}$ & $77.8 \pm 16.5(6) \mathrm{A}$ & - & $82.4 \pm 10.4(10) \mathrm{A}$ & $28.6 \pm 18.4(7) \mathrm{A}$ & $31.6 \pm 5.6(19) \mathrm{AB}$ \\
\hline 14 & $10.2 \pm 3.9(9) \mathrm{B}$ & $50.0 \pm 50.0(2) \mathrm{A}$ & - & - & $0.0 \pm 0.0(3) \mathrm{A}$ & $10.5 \pm 4.5(10) \mathrm{B}$ \\
\hline 6 & $6.2 \pm 6.2(8) \mathrm{B}$ & $66.7 \pm 33.3(3) \mathrm{A}$ & - & $100.0 \pm 0.0(1) \mathrm{A}$ & - & $13.9 \pm 6.7(8) \mathrm{B}$ \\
\hline
\end{tabular}


humifusum is stimulated by fire. Hodgkinson \& Oxley (1990) found that germinability in D. viscosa increased when placed in boiling water for five seconds, but seed was killed by slow burning litter fires when temperatures exceeded $80^{\circ} \mathrm{C}$.

Species that do not germinate in response to fire, like E. cupressiformis, could lose soil seed through overheating. However, the effect of reduction in seed input consequent upon cessation of reproductive activity while individuals recover vegetatively from fire may be a more substantial influence on seed numbers. Exocarpos cupressiformis and D. viscosa are heavily grazed by macropods (JBK, personal observation), which may inhibit their establishment after fires create green pick. Infrequently burned areas have greater densities of these species than more frequently burned areas. Purdie \& Slatyer (1976) note that post-burn populations of $A$. humifusum are smaller than pre-burn populations, therefore the decrease in seed numbers for this species may also be related to smaller population sizes in more frequently burnt areas. More frequent fires equate to shorter interfire intervals. Therefore, insufficient time to set seed may explain low seed abundance. To allow successful flowering and seed set, Benson (1985) recommends a minimum fire-free period of nine to 10 years for eucalypt-dominated scleromorphic vegetation.

Bekker et al. (1998) found a strong negative correlation between seed longevity and the depth distribution of seeds, indicating that seed longevity is reduced in the surface layer. The heat associated with fire destroys organic matter (Humphreys \& Craig 1981) and contributes to deterioration of porosity and increased erosivity (Certini 2005). Thus fire can be linked to soil compaction and reduced incorporation of seeds into the soil. This may partially explain the reduced viability in native and $A$. humifusum seeds in the areas burnt more frequently. That Acacia and D. viscosa were not affected in a similar manner may be explained by the dispersal of Acacia seeds into lower soil layers by ants, and by the small size of $D$. viscosa seeds, as smaller seeds are more likely to work their way down soil cracks (Bekker et al. 1998).

The conservation significance of the fire-related seed bank dynamics intimated by our data varies between the obligate seeder species and those with capacity for vegetative recovery from disturbance. As resprouters, as well as contributors to a persistent seed bank, species such as E. cupressiformis and $A$. humifusum are doubly buffered against disturbance or the lack thereof. Thus, $A$. humifusum can survive fire by resprouting, and survive elimination in the vegetation by light competition through its soil seed store, whereas the obligate seed regenerators D. viscosa and B. viscosa might be eliminated from an area if frequent fires exhaust their seed banks. Our data suggest that at least one major weed species, $R$. fruticosus, builds up its seed store as time elapses after fire. Such a mechanism may account for the prominence of exotic shrubs in long unburnt bush (Watson et al. 2009). There may thus be a tradeoff between maintaining obligate seeding natives and mitigating weed invasion. In the case of our study area, an interval between fires of less than 11 years is likely to lead to the elimination of $D$. viscosa, which takes this time after germination to release seed into the soil store (JBK, personal observation).

\section{CONCLUSION}

Ours is the first study of the effects of fire history on the soil seed bank of large-seeded geosporous species in a Tasmanian scleromorphic ecosystem. Out of six native large-seeded species the abundance of two species, Astroloma humifusum and Exocarpos cupressiformis, generally declined in the seedbank with more frequent and recent fire. This may be due to germination triggered by fire, selection against these species by fire, insufficient maturation periods between fire and reduced total seed output and population size due to repeated burning. A significant reduction in seed viability in natives and $A$. humifusum was also related to fire history, possibly reflecting loss of viable seed to germination.

\section{ACKNOWLEDGEMENTS}

We thank Jon Marsden-Smedley for assistance with mapping.

\section{REFERENCES}

Auld, T.D. 1986: Population dynamics of the shrub Acacia suaveolens (Sm.) Willd.: Dispersal and the dynamics of the soil seed-bank. Australian Journal of Ecology 11(3): 235-254.

Auld, T.D. \& Denham, A.J. 2006: How much seed remains in the soil after a fire? Plant Ecology 187: 15-24.

Bekker, R.M., Bakker, J.P., Grandin, U., Kalamees, R., Milberg, P., Poschlod, P., Thompson, K. \& Willems, J.H. 1998: Seed size, shape and vertical distribution in the soil: indicators of seed longevity. Functional Ecology 12: 834-842.

Bell, D.T. 2001: Ecological response syndromes in the flora of southwestern Western Australia: fire resprouters versus reseeders. The Botanical Review 67: 417-440.

Benson, D.H. 1985: Maturation periods for fire-sensitive shrub species in Hawkesbury sandstone vegetation. Cunninghamia 1: 339-349.

Certini, G. 2005: Effects of fire on properties of forest soils: a review. Oecologia 143: 1-10.

Fenner, M. 1985: Seed Ecology. Chapman \& Hall, London: 57 pp.

Fryer, R. 2006: Seed germination records. In Sweedman, L. \& Merrit, D. (eds) Australian Seeds. A Guide to their Collection, Identification and Biology. CSIRO Publishing, Victoria: 199-219.

Gilfedder, L. \& Kirkpatrick, J.B. 1993: Germinable soil seed and competitive relationships between a rare native species and exotics in a semi-natural pasture in the midlands, Tasmania. Biological Conservation 64: 113-119.

Harper, J.L. 1977: Population Biology of Plants. Academic Press, New York: 84 pp.

Hodgkinson, K.C. \& Oxley, R.E. 1990: Influence of fire and edaphic factors on germination of the arid zone shrubs Acacia aneura, Cassia nemophila and Dodonea viscosa. Australian Journal of Botany 38: 269-279.

Humphreys, F.R. \& Craig, F.G. 1981: Effects of fire on soil chemical, structural and hydrological properties. In Gill, A.M., Groves, R.H. \& Noble, I.R. (eds) Fire and the Australian Biota. Australian Academy of Science, Canberra: 177-200.

Knox, K.J.E. \& Clarke, P.J. 2006: Fire season and intensity affect shrub recruitment in temperate sclerophyllous woodlands. Oecologia 149: 730-739.

Koch, J.M., Ruschmann, A.M. \& Morald, T.K. 2009: Effect of time since burn on soil seedbanks in the jarrah forest of Western Australia. Australian Journal of Botany 57: 647-60. 
Lunt, I.D. 1997: Germinable soil seed banks of anthropogenic native grasslands and grassy forest remnants in temperate south-eastern Australia. Plant Ecology 130: 21-34.

Meney, K.A., Nielssen, G.M. \& Dixon, K.W. 1994: Seed bank patterns in Restionaceae and Epacridaceae after wildfire in kwongan in south western Australia. Journal of Vegetation Science 5: 5-12.

Merritt, D. \& Rokich, D. 2006: Seed biology and ecology. In Sweedman, L. \& Merrit, D. (eds): Australian Seeds. A Guide to their Collection, Identification and Biology. CSIRO Publishing, Victoria: 19-24.

Minitab Inc 2010: Minitab Users Guide Release 16. Minitab Inc: USA.

Morrison, D.A., Cary, G.J., Pengelly, S.M., Ross, D.G., Mullins, B.J., Thomas, C.R. \& Anderson, T.S. 1995: Effects of fire frequency on plant species composition of sandstone communities in the Sydney region: Inter-fire interval and time-since-fire. Australian Journal of Ecology 20: 239-247.

Ooi, M.K.J., Auld, T.D. \& Whelan, R.J. 2007: Distinguishing between persistence and dormancy in soil seed banks of three shrub species from fire-prone southeastern Australia. Journal of Vegetation Science 18: 405-412.

Penman, T.D., Binns, D.L., Allen, R.M., Shiels, R.J. \& Plummer, S.H. 2008: Germination responses of a dry sclerophyll forest soil-stored seed bank to fire-related cues. Cunninghamia 10: 547-555.
Pierce, S.M. \& Cowling, R.M. 1991: Dynamics of soil-stored seed banks of six shrubs in fire-prone dune fynbos. The Journal of Ecology 79: 731-747.

Purdie, R.W. \& Slatyer, R.O. 1976: Vegetation succession after fire in sclerophyll woodland communities in south-eastern Australia. Australian Journal of Ecology 1: 223-236.

Terry, J., Probert, R.J. \& Linington, S.H. 2003: Processing and maintenance of the Millennium Seed Bank collections. In Smith, R.D., Dickie, J.B., Linington, S.H., Pritchard, H.W. \& Probert, R.J. (eds): Seed Conservation. Turning Science into Practice. Royal Botanic Gardens, Kew: 307-325.

Vaughton, G. 1998: Soil seed bank dynamics in the rare obligate seeding shrub, Grevillea barklyana (Proteaceae). Australian Journal of Ecology 23: 375-384.

Watson P.J., Bradstock, R.A. \& Morris, E.C. 2009: Fire frequency influences composition and structure of the shrub layer in an Australian subcoastal temperate grassy woodland. Austral Ecology 34: 218-32.

Wilkinson, G.R. \& Jennings, S.M. 1994: Regeneration of blackwood from ground-stored seed in the North Arthur forests, north-western Tasmania. Tasforests 6: 69-77.

(accepted 5 November 2013)

\section{APPENDIX 1 \\ Characteristics of seed types}

\begin{tabular}{|c|c|}
\hline Species & Description \\
\hline Exocarpos cupressiformis & ovoid and dark brown, with three suture lines on top \\
\hline Dodonea viscosa & globular, black and shiny, with a flattened rim (pl. 1F) \\
\hline Astroloma humifusum & $\begin{array}{l}\text { trigonous seeds contained within a woody, multi-chambered, ellipsoid capsule with longitudinal furrows } \\
\text { (pl. 1D) }\end{array}$ \\
\hline Lepidosperma laterale & ellipsoid with brown casing, white when casing removed, and with a capitate embryo (pl. 2F) \\
\hline Beyeria viscosa & oblong with a flat face at the attachment end (pl. 1E) \\
\hline Acacia spp. & seeds variably black, shiny, obovate or oblong (pl. 1A-C) \\
\hline Rubus fruticosus & triangular and flattened along radial axis, tan to light brown, with a reticulate surface \\
\hline Passiflora tarminiana ${ }^{1}$ & cordiform, dark brown, with a pitted surface (pl. 2D) \\
\hline Vicia sp. ${ }^{1}$ & globular with a smooth speckled brown and green surface, and a distinctive hilum (pl. 2E) \\
\hline Galium sp. ${ }^{1}$ & spheroidal, dark brown, with finely netted ridges and a deeply depressed hilum (pl. 2C) \\
\hline Plantago sp. ${ }^{1}$ & elongate, with longitudinal faces and characteristic side-attachment (pl. 2A) \\
\hline Cotoneaster sp. ${ }^{1}$ & $\begin{array}{l}\text { ovate, widest at the attachment end, with one flattened face, light brown to tan, with some retaining the } \\
\text { peduncle (pl. 2B) }\end{array}$ \\
\hline exotic seed $1{ }^{1}$ & variably spheroid, woody, with a single chamber \\
\hline exotic seed 21 & large, woody, with the two halves overlapping \\
\hline
\end{tabular}

${ }^{1}$ exotic taxon 

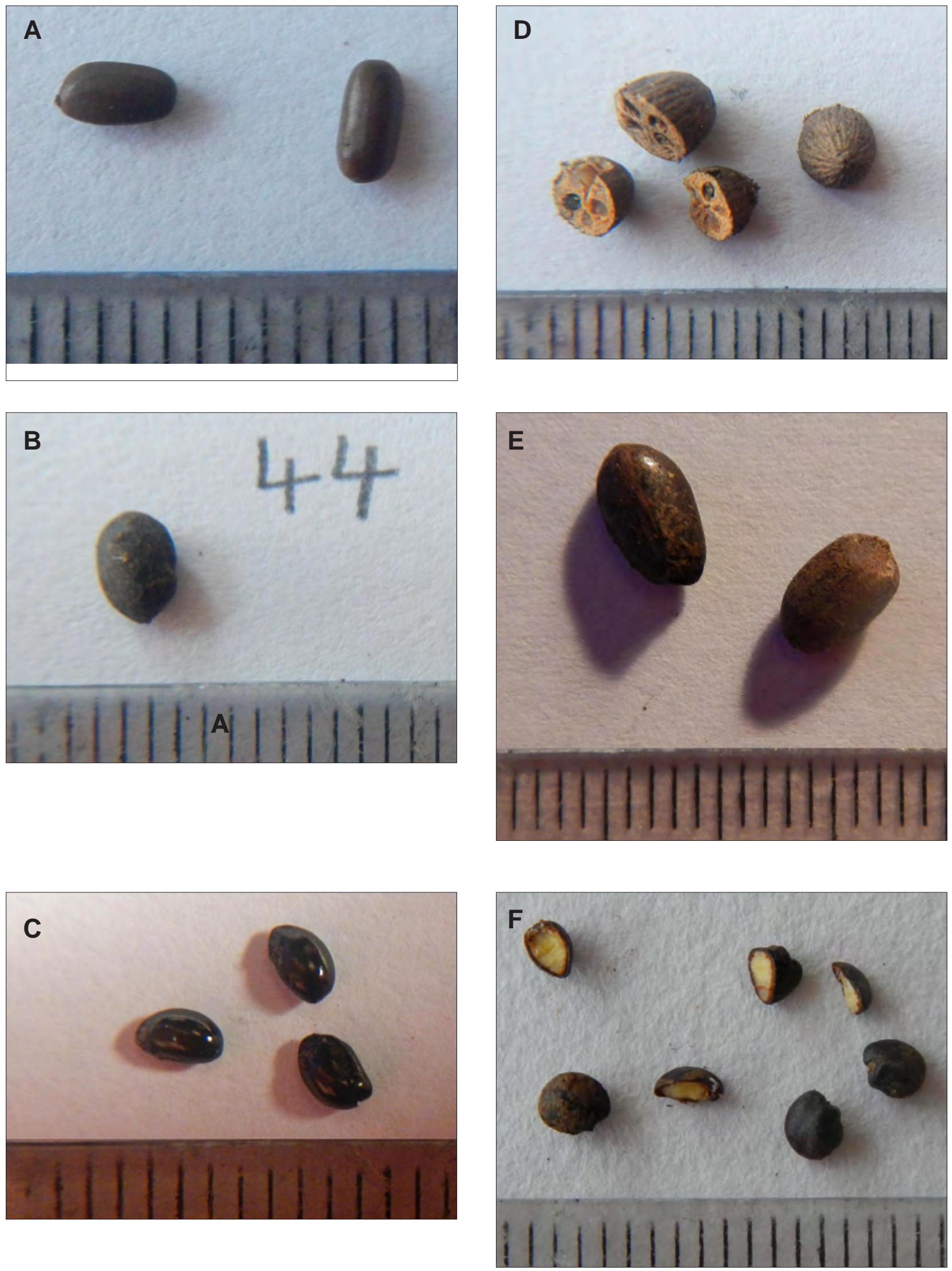

PLATE 1

(A) Acacia sp. 1; (B) Acacia sp. 2; (C) Acacia sp. 3; (D) Astroloma humifusum; (E) Beyeria viscosa; (F) Dodonea viscosa. Scales in millimetres. 

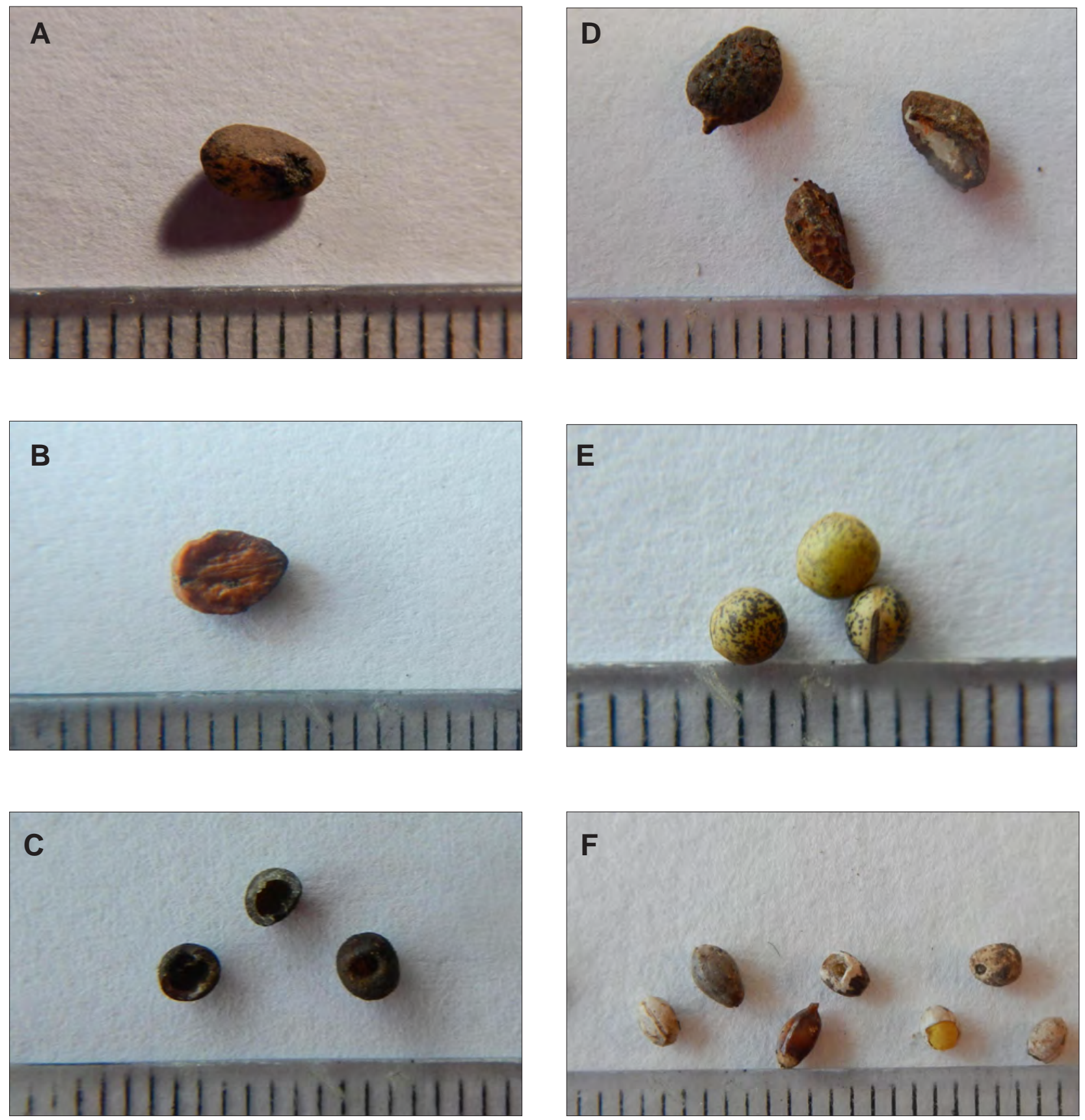

\section{PLATE 2}

(A) Plantago lanceolata; (B) Cotoneaster sp.; (C) Galium sp.; (D) Passiflora tarminiana; (E) Vicia sp.; (F) Lepidosperma laterale. Scales in millimetres. 